\title{
URBAN AND ARCHITECTURAL PERFORMANCES IN THE FUNCTION OF DEFINING OF STRATEGY OF SUSTAINABLE DEVELOPMENT OF TOURIST DESTINATION
}

\author{
Spasoje Tuševljak ${ }^{1}$ (D) \\ Miodrag Simović ${ }^{2}$ \\ Vladimir Simović ${ }^{3}$ \\ Ivan Tuševljak ${ }^{4}$
}

DOI: https://doi.org/10.31410/ITEMA.2019.19

\begin{abstract}
Development of science and positive practice are increasingly emphasizing the importance of multidisciplinary approach in resolving problems in the domain of nature, society and economy, and in particular problems generated by interaction of various factors of influence of apostrophized strategic areas. As diverse the factors of action are, diversity of character of action by areas and synergy is manifested even more, which emphasizes the need for planning and monitoring of effects. In this context, observed relationships between natural, social and economic structures indicate the lack of indigenous self-regulation by fields and the complexity of synergy and interactions. As the whole paradigm is situated in a given milieu, from micro location to universe, the role of space becomes important, placing spatial planning, urbanism and architecture as scientific disciplines dealing with the phenomenology of space, its significance and effect on the phenomena of nature, society and economy, sequentially and as a whole.
\end{abstract}

Keywords: Spatial Planning, Architecture, Development, Ownership, Institutions.

\section{INTRODUCTION}

Q patial planning includes a wide range or relevant natural, technological, economic and social $\checkmark$ factors, having the intention to formulate principles and aims of sustainable development by optimizing available factors within given spatial framework. As it is natural that potentials and resources are situated in the space, so is natural interdependence of economic activities and space, as well as pluralism and rivalry of ownership portfolio and interests, which emphasize the significance of legal regulation and functionality and stability of institutional settings.

Tourism has become an economic branch on the rise thanks to numerous circumstances, before all globalization of world economy, growth of mobility of production factors, but also autochthonous specificities of business itself that opens optimistic perspectives to everyone; for development, growth of employment and compensation of losses caused by globalization and liberalization of market with negative implications in many sectors and branches. Comparative advantages as those exotic natural circumstances, attributes and characteristics undeveloped countries have - are not sufficient for use for tourism development dynamization. A sophisticated view of all circumstances is needed to effectively valorize human and material resources

\footnotetext{
$1 \quad$ University of Economy of East Sarajevo, Alekse Šantića 3, 71240 Pale, Bosnia and Herzegovina

2 Constitutional Court of Bosnia and Herzegovina, R.Dž.Čauševića 6/III, 71000 Sarajevo, Bosnia and Herzegovina

3 Prosecutor's Office of Bosnia and Herzegovina, Kraljice Jelene 88, 71000 Sarajevo, Bosnia and Herzegovina

$4 \quad$ Preduzetnik.IT, Stari Grad, Belgrade, Serbia
} 
the country has, which implies the creation of development strategies, economic and current policies with a sophisticated and forward-looking approach to achievement of future goals.

Spatial planning encompasses a wide range of relevant natural, technological, economic and social factors in order to formulate the principles and goals of sustainable development by optimization of available factors within given spatial framework, so as to distinguish between local, regional, national and transnational spatial planning documents and concepts. Urbanism, on the other hand, defines the conditions and mechanisms of operational purpose with the aim of harmonization and optimization of natural, social and economic performances for generating of sustainable development, while architecture creates functional and aesthetic dimensions of use and visual recognition. As it is natural that potentials and resources are located in space, so is natural and necessary appropriate legislation that regulates all the aspects in a creative and effective manner, connections and interactions of economic activities and spaces.

\section{URBANISM AND ARCHITECTURE AS FRAMEWORK FOR FORMULATING THE TOURIST DESTINATION DEVELOPMENT STRATEGY}

The urban framework and architectural solutions primarily determine the attractiveness of tourist destination, but also business opportunities and effects of functional and aesthetic performances, in general and in details, which is certainly the most important. Unfortunately, the circumstances of poor and underdeveloped countries are such that the lack of money, knowledge, vision and functional institutions is most often compensated by ad hoc improvisation, which generates errors that are difficult to eliminate and expensive.

Of course, not even the richest people are immune to mistakes, but they are less frequently made and easier to repair. However, the impression is that the area of spatial planning and architecture is important only insofar as it allows political and investment elites to provide "soft" mobility and low costs at a certain moment, which in the long term limits the possibilities of valorization, but also multiplies social expenditures on various basis, now and in future.

In order to come up with solutions that optimize the valorization of potentials, a sophisticated research approach is needed when formulating strategies and operational mechanisms for implementation. This approach is sui generis challenging in the context of Jahorina tourist destination, due to growing disparity between fascinating natural performances and huge social and private investments, on the one hand, and realized exploitation effects, on the other, that worryingly stagnate and threaten the survival. It must be noted that the existing situation was significantly negatively influenced by urban-architectural solutions.

It is extremely important for a tourist destination that it is urbanistically functional and architecturally recognizable, which is not only a picture of the landscape and visual identity that visitors will take with them, but also the basis on which commercial and business strategies are built. In order to create conditions for formulating commercial and business strategies and their functional harmonization, it is necessary to first build mechanisms for defining spatial planning strategies and architectural solutions frameworks.

Infrastructure potential and concept of visual recognizability is formatted by the strategy of spatial planning and framework of architectural solutions, which is at the same time basis for formulating competitive business strategies and their operationalization. Spatial planning 
should look at the totality of natural, economic and demographic potentials in the context of goals that are to be achieved, now and in the long term. It is an unquestionably complex mission that entails a multidisciplinary approach, which generates complications in coordination and harmonization of diverse doctrinal and methodological approaches and propositions.

It is a long and complex journey from vision, concept and instruments, to planning documents and institutional operationalization, that, perhaps most expressive, describes a well-known Latin proverb "per astera ad astra". The paradigm of the phenomenon is compounded by the fact that spatial planning formulates vision, performance strategies and instruments that effectively affect economic, legal, social, demographic and employment status and perspectives, which certainly implies branch, regional, local, but also political controversies and rivalries.

The study of the impact of urbanism and architecture on the position and perspectives of sustainable development of Jahorina tourist complex is indisputably intriguing and significant not only in the context of apostrophized aspects, but also in the context of assessment of the possibilities for overcoming of generated constraints in order to create better conditions for businesses to grow their competitiveness and profitability. .

\section{CULTURAL HERITAGE, SOCIAL AND ECONOMIC CIRCUMSTANCES AND THEIR IMPACT ON THE PROCESS OF FORMULATING AND PROJECTING OF URBAN AND ARCHITECTURAL PERFORMANCES}

Urban and architectural vision is primarily determined by heritage, level of technocratic development of the profession and talent and gift of architect. In doing so, vision is always situated in given socio-economic context, which defines the goals to be achieved, as well as the means and instruments for the realization of set goals.

An analysis of the current state of urban functionality and architectural recognizability indicates that the existing configuration is the result of ideological heritage and preferences of social and political factors whose primary goal was to meet the needs of social groups, so that market valorization was at the second place. According to such preferences, established goals were not primarily economic but social and propaganda in a way that rest and recreation could be used by workers and their families, unions, youth and ferrymen under privileged conditions, with a wide range of socialization and loss recovery mechanisms.

In such conditions, many companies and institutions have built capacities "by directive" without necessary complete urban and architectural projects, but also without professional elaborations and economic feasibility projects. This has resulted in activation of numerous construction and infrastructure facilities without institutionally authorized building and use permits and resolved ownership status.

The mortgage of (ir)reparable failures from the past complicates resolution of cumulated problems, as in sphere of value system so as in profiling of vision for the market environment and inexorably harsh economic conditions, which economic theory classifies as a model of complete competition. In this context, a new strategic role and generated reach of urbanism and architecture in development of economy and society as a whole should be formulated, which in modern conditions implies a multidisciplinary approach and sophisticated future forecasting mechanisms in order to create solutions of a higher degree of reliability in assessment of changes. 
At the present moment, the circumstances are further complicated by the persistent crisis, which discourages investors and limits investment opportunities, and without additional investments for optimization of urban performances, it is not possible to revitalize the yield potential of existing capacities or to build new ones. The problem is all the greater because significant investments are also needed to improve financial position and for financial consolidation, which in given circumstances is impossible without adequate support and interventions from social funds.

What to choose as a priority for investment in case of limited resources - optimization of urban performances or consolidation of financial position, is a question for economic policy makers, which the fate of Jahorina tourist complex depends on, in many respects. The problem is additionally complicated by both the ideological confusion caused by transition and lack of answers for overcoming of economic crisis, as well as political conflicts, improvisation and lay arbitration when selecting economic policy priorities that, instead of growth, produce regional rivalries and animosities, as well as branch and structural mismatches. Such circumstances clearly affect the neglect of the potential of touristic economy as a whole, and consequently the potential of the Jahorina tourist destination, although this economic branch has a pronounced multiplier effect on the growth of the conjuncture, employment and GDP.

Optimization of urban performances is extremely important for the market valorization of tourist complex potential, as it creates the conditions for the revitalization of the yield position through diversification of supply. The revitalization of the yield position is unthinkable without urban situation of the conditions for infrastructure investments, new facilities on offer, traditional crafts and production, including complementary sectors which create circumstances for full utilization of capacities in season and "off-season".

Unfortunately, economic crisis is not the only limiting factor for creating of innovative urban concept and architectural recognition. Limiting factors are also lack of knowledge and good practice, neglect and marginalization of profession and aforementioned absence of a systematic approach, long-term vision and harmonization of branch, regional and strategic performances, which limits planners to create functional spatial plans for a dynamic and sustainable economic development. In the conditions of globalization, where market mechanism and the principle of competitiveness dominate, the incompleteness and imperfections of urban performances radically limit business opportunities of economic entities.

\section{A NEW URBAN-ARCHITECTONIC VISION OF JAHORINA TOURIST DESTINATION IN THE FUNCTION OF GROWING BUSINESS PERFORMANCES AND DYNAMIZATION OF DEVELOPMENT}

From the very beginning, development of the Jahorina tourist destination took place in the context of a poor country, where the first steps were taken by enthusiasts and proprietors inspired by the beauty of the landscape and the extraordinary natural and climate conditions of the complex. Although prosperity periods and certain significant events, before all the 1984 Winter Olympics, generated investment and development conditions for tourism, the approach and philosophy of development did not change significantly, as this resource is recognized as a complex rather than a tourist destination, which is not just a semantic difference.

In architectural and urban terms, the complex is understood as a set of objects and functional possibilities for realization of program contents and the needs of users, while destination im- 
plies a broader context of attractions, organization and functions, which unambiguously indicates both larger functional possibilities and scope, as well as evident commercial potential and promotional recognizability. In that sense, Jahorina is still positioned as a complex today rather than a tourist destination, because of the vision of development up to date, planned interventions and inadequately perceived implications, but also because of negative political changes, the dissolution of the country, wars, devastation of infrastructure and facilities.

Due to improvisation and the absence of systematic approach in formulating a development vision, strategic decision makers have for many years preferred the development of skiing infrastructure and accommodation capacity without fully considering the possibilities generates integrated and harmonized infrastructure setting. Infrastructure setting cannot be optimized without a creative vision and strategic spatial planning that defines the construction conditions by urban-architectural mechanisms, broad enough, but also with important details and necessary coverage in spatial and substantive sense. Otherwise, all approaches that favor a single infrastructure segment significantly limit urban planners and architects, so that designed solutions appear as a limiting framework for valorization of potential.

The current state of urban and architectural performances is not at a level that would allow restructuring of the complex and its transformation into a prestigious tourist destination without redefining the concept of development and significant investments. The new approach should be conceived on contemporary spatial planning principles by formulating the interaction mechanisms of natural, social and economic resources to generate sustainable development.

In such an approach, it is important to create urban and architectural solutions, based on analytical view of the current situation, that will enable functional parameters for valorization so as to effectively use all the opportunities provided by: (1) existing facilities and infrastructure of the complex for creating of contents enabling diversification of offer and the growth of capacity utilization scale by taking advantage of all comparative advantages of natural and economic parameters, (2) social infrastructure in the immediate hinterland (East Sarajevo and Sarajevo), (3) complex hinterland; rural regions in the Northeast, East and Southeast and urban hinterland of East Sarajevo and Sarajevo in the West, and (4) contemporary science of spatial planning in order to formulate urban architectural determinants for achieving of sustainable development.

1. Existing facilities and infrastructure of the complex allow significant improvements and redefining of urban solutions, which should be used to interpolate sports, recreation, cultural events, seminars, congresses, student and professional events and meetings, art colonies, festivals and happenings, with interventions to improve and diversify the contents of operational logistics, in order to create conditions for diversification of offer and transition from seasonal to year-round business. Certainly, in all of this it is necessary to revitalize promotional activities, with serious systematic effort and rehabilitation of Jahorina as an Olympic mountain and rare and exceptional tourist resource. Focusing on urban-architectural settings and prioritizing new investments is a rational solution given the circumstances of the crisis and limited funding sources.

2. An impressive and representative social infrastructure in the near hinterland is undoubtedly developmental advantage that should be used to address strategic and operational constraints, both in the development and business domains, with intention to generate partnerships in the implementation of projected sustainable development goals. 
3. The effort to create mechanisms for valorization of potentials of rural environment of gravitational regions in the East and urban hinterland of East Sarajevo and Sarajevo in the West by creating conditions for development of traditional businesses and crafts, their promotion and branding in the function of offer diversification, is of great importance, which will stimulate demand growth not only in the urban hinterland, but beyond.

4. Contemporary science of spatial planning has largely affirmed a multidisciplinary approach to the studying of this phenomenon, emphasizing the need to harmonize natural, social and economic performances in order to achieve long-term sustainable development, which is ultimately a strategic civilization act. Scientific propositions and good practice analysis in this field benefit small underdeveloped economies in formulating sustainable development strategies, with the phenomenology of space being an extremely complex and demanding issue that implies the necessity of continuous, sophisticated professional care and regulation, in order to generate optimal contribution to economic and social development, and maintain natural balance.

Encouraging is the fact that, both at global level ${ }^{5}$ (in Europe) and domicile (in the Balkans), operational efforts and measures have been evident for almost 90 years to affirm and apply scientific principles and propositions of functioning in this important area through normative and management actions, which resulted in the adoption of appropriate documents that sought to achieve certain harmonization and standardization of solutions. Thus, in 1933, the European Council of Spatial Planners (ECSP) adopted the Athens Charter, and in 1998 issued a new Athens Charter with the ambition to address the problems and recommend ways to address many challenges of spatial development at the threshold of the new century. The new Athens Charter has undergone appropriate adjustments and revisions at the 2003 and 2010 meetings, and the revised text entitled "European Spatial Planning Charter" was adopted at the ECSP Assembly held in Barcelona in 2013. It is expected that recognizing the importance of space will provide effective mechanisms for eliminating the negative implications that have generated incompetent managerial decisions and improvisations at the global and local level in the past on natural, social and economic structures.

\section{CONCLUSION}

This paper not only highlights the basic doctrinal and methodological determinants of urban-architectural solutions, procedures and actions, but also addresses their importance in the process of creating effective economic development strategies, with basic message that only an interdisciplinary approach can reliably view all relevant aspects of this complex phenomenon. Confirmation of principle points of view is also found in the analysis of economic position of the Jahorina tourist complex, where it is evident that one of the important causes of the crisis is the neglect of the importance of spatial planning, urban and architectural performances in profiling infrastructural conditions for a sustainable development. Neglecting the importance of spatial planning, urbanism and architecture has negative implications for development, because infrastructure often appears as a limiting factor of diversification and business adaptation to changing economic conditions.

As in the current conditions of globalization, competition, information and mobility of factors are increasing - the risks of survival of companies, industrial branches and sectors are also increas-

5 Development of European strategies and spatial development and planning policies is carried out through activities of two central European organizations - Council of Europe and European Commission. 
ing, if available potentials in the necessary and sufficient volume are not valorized. Valorization of potentials is influenced by numerous factors and mechanisms of combining them within a given framework, that is, space, and above all material resources, knowledge and organization.

Everything is located in space; nature, society and economy with dynamic interactions that disrupt the balance of the system by generating risks that endanger functioning and threaten the survival of the entities individually and of the system as a whole. This knowledge has primarily contributed to positioning the principle of sustainable development as a universal point of view and the principle of civilization, in which the dimension of space has a dominant importance and determination. Because of the risks that complicate functioning and endanger survival, planning that effectively adjusts space performances and creates conditions for optimizing potential valorization and sustainable development is required.

Due to the lack of systematic approach and sophisticated vision, urban solutions, which position Jahorina primarily as a ski resort are preferred, which is not enough for sustainable development in areas with a stable season of six to eight months or longer, without urban solutions, infrastructural and business portfolio extending the season from ten to 12 months. In addition to other shortcomings in the business portfolio, neglecting the importance of architectural recognition of facilities, landscapes and environment has significantly limited the positioning of this remarkable natural treasure as a prestigious and prosperous tourist destination.

\section{REFERENCES}

Fukujama, F. (2002). Kraj istorije i poslednji čovjek. Beograd: CID, Romanov.

Korica, R. (2008). Infrastruktura, saobraćaj, urbanizam, arhitektura. Beograd: Arhitektonski fakultet Univerziteta u Beogradu.

Saks, D.D. (2014). Doba održivog razvoja. Beograd: CIRSD and JP “Službeni glasnik".

Tuševljak, S. (2014). Treba (li) nam nacionalni program izlaska iz krize - Šta (ni)smo mogli to nismo razumjeli. Beograd: Srpska akademija nauka i umjetnosti.

Tuševljak, S. (2017). Institicionalna ekonomija danas - šta (ne) možemo uraditi bolje, Zbornik radova - Naučni skup „Ekonomija danas, Institucije i ekonomija - šta (ne)možemo uraditi bolje“, Univerzitet u Istočnom Sarajevu, Andrićgrad, 1. i 2. septembar 2017.

Tuševljak, S. \& Tomić, Ž. (2015). Doctrinal and management controversies of debt growth of small open economies in terms of globalization -What must or need not the Republic of Srpska and Bosnia and Herzegovina do? Univerzitet Nižnji Novgorod

Simović, M., Jovašević, D. \& Simović, V. (2016). Privredno kazneno pravo. Istočno Sarajevo: Pravni fakultet. 